\title{
Training Culture and Employees Performance in Nepali Banking Industry
}

Prakash Kumar Gautam*

\begin{abstract}
Training culture is the aggregate of meaning, values, practices, attitude and behavior as to invest in training and development so that organizational knowledge and skills could be enhanced. Advanced knowledge, capabilities and skills are proved to be source of competitive advantage of the organization as these assets hold dominant role in customer's satisfaction and retention. Organizations have two choices as to acquire competent employees from the industry or to build their competencies. The second choice becomes more appropriate from organizational image, employee satisfaction and retention along with the improved performance. Organizations, thus, need to establish a training culture for sustainable growth of organization. It could be the only way to reduce the cost of hiring competent employees and reducing the cost of losing competent employees. Performance of the employees can be sustained with training. This study aims to examine whether Nepali banking sector has established training culture? If yes, whether training has significant influence in performance? This study follows descriptive and correlational research design. Structured questionnaire with 5-point Likert scale is used to collect the information. Mean, standard deviation, correlation and independent sample t-test are used to analyze the data. Result revealed that Nepali banks have established the training culture. Training environment, training methods, training-reward linkage are the major factors of training culture affecting training satisfaction and employee performance. Employees are satisfied through the skills acquired from training. Gender and the bank types have mediating role in training satisfaction and employee performance.
\end{abstract}

Key Words: Training environment, Training culture, Training-reward linkage, Training methods, Employee performance

\footnotetext{
${ }^{\star}$ Lecturer, Faculty of Management, Tribhuvan University, Nepal Email: gdpconsultingnepal@gmail.com
} 


\section{Background of the study}

Globalization has changed the shape of business in every sector. Jobs demand advanced skills and competencies sustain the business in steeping up competition. Each organization whatever may be the nature, tries to dig-out new methods of production and value driven supply system for service to optimize the customer satisfaction. They need to trim down the cost in order to increase profit which is possible only through advance technology and advanced skills of the employees. Attaining goals of changing technology and employee motivation is not easy task but can be ensured through increasing level of confidence through training and development. Organizations have no choice to use employee's skills at the level best either through acquiring competent employees from the industry or sharpening the skills and competencies of existing employees. Getting competent employees from the industry becomes costlier. It has increased the significance and emergence of institutionalizing training culture in organizations and hence, banking sector cannot remain in isolation.

Training is the process of enhancing specific skills of employees required for current job. It is the basis of employee performance to meet the demand of job they are involved. Training is a tool to remove skill deficiency of employees and rectify the behavior. Employee training is the only planned strategy for facilitating employees to enhance jobrelated knowledge, skills

and behavior. Principally, trained employees get satisfied from their job and environmental conditions. The more the level of satisfaction from the job, the more they improve job performance. This creates synergy in the organization which proves that training increases the organizational performance as predicted by many researches (Peteraf \& Naizi, 1993). Employees are the indispensable assets as they are source of competitive advantage of any organization (Garman, et al., 2003). Ability of any organization to train its human resource to be creative, innovative, inventive leads enhancing performance and increase competitive advantage (Chiaburu, et al., 2005).

The highly trained and motivated employees are the powerful source of competitive edge among all resources. To develop the desired knowledge, skills and abilities of the employees, to perform well on the job, requires effective training programs that may also effect employee motivation and commitment (Smith, 2000).

On-the-job and off-the-job both training methods need to be institutionalized in the organizations as training culture making training as reutilized activity. Singh (2014) stated that both on-the-job and off-the-job training method have positive and significant relationship with employee performance. Training affects organizational competitiveness, revenue and performance. Unfortunately, majority of government, private and even international organizations are not realizing the importance of training culture in their 
organizations to increase productivity. Many organizations take first option to cut their budget of training when the economy slows down or profits gets decline. Many empirical evidences prove that training and employee performance are positively associated to achieve organizational goals. In competitive business environment, organizations need to provide better product and services at lower price.

It is constant need to identify the training need in individual level, group level as well as the organizational level, motivate employee towards training, providing training opportunity unbiased to all the employees. Translating the training skills at job is more challenging task in establishing and institutionalizing training culture in organization. Thus, there must be a training culture in each organization. But, there is ever lasting debate among the professionals and academicians regarding the effect of training on both employee as well as organizational performance. A lot is known about the economics of training in the developed world, studies of issues associated with training in less-developed countries (Hameed \& Waheed, 2011).

Employee training has direct impact on productivity and growth (Chaudhary \& Sharma, 2012). Hossain and Hossain (2012) revealed that non-financial factors like training have a significantly higher impact on the employee's motivation than the financial factors. Shahzadi (2014) reported a significant positive relationship between training and employee performance.

Bulut and Culha (2010) revealed that training has a positive influence on employee commitment focusing on employees' emotional and affective field. Positive and significant relationship has established with job characteristics, innovative personality and organizational support and training and development (Battistelli, 2009). Khan (2012) concluded that training contributes greatly to employee's performance in comparison with other factors like motivation, technology, management behavior, and working environment. The result concluded that organization having good training plans for employees can enhance the performance of employees. Likewise, Saeed and Asghar (2012) examined the essence of training and development efforts of organization and employee's job performance indicators. The empirical result stated that there is positive and significant relationship between training and employee's job performance. Training not only develops the skills of employees but also sharpens their creativity and assertive behavior. Training also enables employees to deal with the customer in an effective manner and respond to their complaints so that customer satisfaction could be increased. Training programs not only develops employees but also help an organization to make best use of their human resources in favor of gaining competitive advantage. It seems mandatory to the firm to set training culture to enhance their abilities and competencies that are needed at the workplace. Training develops self-efficacy and results in superior performance by replacing the traditional practices through efficient and effective work practices. 
Alrawabdeh (2014) examined the relationship between employees' training and development on employees' performance revealed the positive relation between them. A research conducted by Dabale et al. (2014) concluded that the strong evidence between training and employee performance. They further concluded that training develops skills and competences, and reduces learning time. Likewise, Falola et al. (2014) described the effectiveness of training and development on employees' performance and organization competitive advantage in the Nigerian banking industry. Kum et al. (2014) explored the positive impact of training and development on employee performance in the context of Singapore. The study concluded that effective employee training leads to an increase in quality of job with potentially fewer mistakes. Training and development have significant relationship with employees' performance and productivity (Tahir et al., 2014) in Paksistan. Wahab et al. (2014) evaluated the employees' motivation and perception about these training and development program and concluded that there is no systematic and strategic approach for conducting training and development programs in the health sector. Idrees et al. (2015) examined the effect training and development on the job performance of the employees in educational sectors which revealed the positive relationship.

Training Culture as a set of meanings and values attributed to training in a specific organization (Polo, Cervai \& Kantola, 2018). Training Culture establishes the formal learning environment, formulates organizational policies for creating sharing culture, and motivates all the people associated in the organization to create, share and transfer. It is the subset of organizational culture incorporating the meanings and values attributed to the training in the work environment at individual, group, and organizational level. Following Hofstede's (1998) training culture is considered as an attribute of an organization manifested and measured toward individuals aggregated to the level of the organizational unit. This is the rational that culture is more strong construct to understand how training is perceived within the organization and to what extent the perspectives of different members of the organization are similar. The logic behind including all the people in organization i.e. management and employees in the Training Culture definition is due to the fact that cultural analysis should be in managerial perspectives while culture is located in the mental programs of all the members of the organization (Hofstede, 1998).

Organizations, irrespective of their size and nature of business, must retain the best employees, acknowledging their important roles which positively influence on organizational effectiveness. Employee mobility has been increasing as common challenge to the management because of global demand of skilled human capital. In order to cope with such challenge and attain goals, organizations must develop strategies for increasing satisfaction and performance. Training culture can assist in coping with the emerging challenges of turnover, low productivity and decreasing profitability. 
In Nepali banking industry, the competition is ever increasing as there is large number of competitors at one end and at the other, Nepal Rastra Bank, a regulatory organization has continuously pressurized to increase paid up capital and deposit, to decrease cost of service to customers with decrease in spread rate. Organizations are more interested to attract competent and result-oriented employees even with higher job responsibility and additional benefits. This has increased the corporate movement significantly as emerging challenge. To cope with this, banks need to institutionalize the advanced training programs to develop employees' skills and direct their talent tightly towards the bank's objectives. In Nepali context, investing in training and development is being a gaining issue whether it can be one of the important strategies for improving organizational performance. This study therefore, deals with the issues regarding whether there a training culture in Nepali organization or not? If yes, is there any relationship between training culture and employee performance in Nepali banking sector? To fulfil the research objectives, following conceptual framework is adopted.

Training culture dimensions

A. Training environment

- Training need assessment practice

- Duration of training

- Unbiased training opportunity

- Training and development budget

B. Methods of training

- Training methods

- Training material

C. Training-reward linkage

\section{Methodological aspect}

Primarily, this study follows descriptive design to explore the training culture in Nepali banking industry. This study further employs correlational designs to deal with fundamental relations between training and development and employee performance. Employees of the commercial and development banks in Kathmandu are considered as population. 250 Well-structured five point Likert scale questionnaires were distributed to the different level employees of commercial and development banks in Kathmandu. Only 200 (100 of each commercial and development bank) usual questionnaires were collected back which maintained 80 percent of response rate.

The first section of questionnaire dealt with the demographic information of respondents such as age, corporate position, years of job experience at current bank, etc. while the second section was designed to explore the training culture in Nepali banking industry while the section was designed with five point Likert items (1 for strongly dissatisfied, 
2 for dissatisfied, 3 for neither dissatisfied nor satisfied, 4 for satisfied and 5 for strongly satisfied) to examine the relationship between satisfaction through training culture and employee performance. Training environment, training method (on-the-job and off-thejob), training- reward linkage, employee satisfaction and employee performance were included. Cronbach's alpha value was obtained to be 0.823 which provides sufficient evidence of reliability of questionnaire. Descriptive frequency analysis, cross tabulation mean scores of responses, correlation coefficient, independent sample t-test, and hierarchical regression are used as statistical tools to draw conclusion.

\section{Results and Discussion}

92 percent respondents have reported that their organizations organize the training and development programs in regular basis. To examine the training culture, training need assessment practice, duration of training, methods of training, unbiased training opportunity to employees, training and development budget, training material and training-reward linkage are asked to the respondents. Table 1, shows the response regarding the above questions in summarized form :

Table 1

Training culture in banking industry (Combined of both commercial and development banks)

\begin{tabular}{|l|l|l|}
\hline Training culture component & \multicolumn{2}{l|}{ Response } \\
\cline { 2 - 4 } & Yes (\%) & Don't Know/No (\%) \\
\hline $\begin{array}{l}\text { Is there training need assessment in regular basis in your } \\
\text { organization? }\end{array}$ & 84 & 16 \\
\hline $\begin{array}{l}\text { Does your organization follow on-the-job and off-the-job } \\
\text { training as on issue of training? }\end{array}$ & 81 & 19 \\
\hline $\begin{array}{l}\text { Is the training duration for each training session in an } \\
\text { average is sufficient? }\end{array}$ & 89 & 11 \\
\hline $\begin{array}{l}\text { Is there regular training and development budget in your } \\
\text { organization? }\end{array}$ & 99 & 1 \\
\hline $\begin{array}{l}\text { Does your organization provide sufficient training material } \\
\text { in training? }\end{array}$ & 100 & 0 \\
\hline $\begin{array}{l}\text { Do employees get training opportunity unbiased in your } \\
\text { organization? }\end{array}$ & 79 & 21 \\
\hline $\begin{array}{l}\text { Does your organization provide credit or priority to the } \\
\text { trained employees? }\end{array}$ & 88 & 12 \\
\hline
\end{tabular}

Table 1 reveals that Nepali banking industry has set the training culture. Nepal Rastra Bank, a regulatory body of banking sector has enacted the obligatory provision of $3 \%$ of 
the total staff expenses (including all benefits to the staff) as minimum annual training and development budget. This provision has encouraged each bank to institutionalize the training culture.

This part deals with employee satisfaction through training culture of organization. Table 2 shows level of customer satisfaction from the different dimensions of training culture i.e. training environment, methods of training, training-reward linkage.

Table 2

Employee satisfaction from training culture

\begin{tabular}{|l|l|l|l|}
\hline s.n & Dimensions & Weighted mean & S.D \\
\hline 1 & Training environment & 3.43 & 0.72 \\
\hline 2 & Training methods & 4.1 & 0.92 \\
\hline 3 & Training-reward linkage & 4.35 & 0.8 \\
\hline
\end{tabular}

The mean value of each statement representing the training and development environment lies between 3.28 and 3.69 with average mean value of response 3.43 and s. d. 0.72 . This value is above cut-off value 3 indicating respondents are satisfied with the measuring statement regarding T\&D environment. So, it can be concluded that the respondents are satisfied with the training environment.

Among the statement, majority of the respondents (66 percent) agree on statement 'they can discuss openly at training session' with average response 3.63 and s. d. 0.8 this indicates that the training contents can be easily understood. While only 49 percent respondents are satisfied with mean value 3.26 and s. d. 0.83 on the statement I remain fresh till last moment of the training indicating that trainees do not agree with overload training information. The mean value of statements representing the training methods lies between 4.21 and 3.89 with average mean value of response 4.1 and s. d. 0.92 . This value is above cut-off value 3 indicating respondents are satisfied with the measuring statement regarding training methods applied for training. So, it can be concluded that the respondents are satisfied with the training methods used for bank employees.

Among the statements, majority of the respondents (74 percent) agree on statement with average response 4.21 and s. d. 0.93 that they learn effectively because of effective training method. While 54 percent respondents are satisfied with mean value 3.89 and s. d. 1.02 on the statement 'training methods are updated in my organization.' which indicate that the trainers need to adapt advance way of transfer of skills and knowledge.

Likewise, respondents have shown their satisfaction towards training-reward linkage with mean average mean value 4.35 and s. $\mathrm{d} 0.8$ indicating that training program is linked with promotion, transfer, job rotation, growth opportunity, salary and benefits. Average response on various statements representing the training-reward linkage lies between 4.5 
and 3.91. This value is above cut-off value 3 indicating respondents are satisfied with the measuring statement regarding training-reward linkage in the organization. So, it can be concluded that the respondents are satisfied with the training-reward linkage in bank.

Among the statements, majority of the respondents (79 percent) agree on statement with average response 4.35 and s. d. 0.95 that respective banks of respondents have provision of giving value i.e. priority on promotion and other benefits. While 58 percent respondents are satisfied with mean value 3.91 and s. d. 0.87 on the statement 'trainees get immediate benefits after training.'

This section deals with employee satisfaction from training culture and employee performance in Nepali banking industry. Table 3 shows the mean satisfaction with the statement stating performance of employees.

Table 3

Performance satisfaction from training culture

\begin{tabular}{|l|l|l|}
\hline \multicolumn{1}{|c|}{ Statements } & Mean & SD \\
\hline $\begin{array}{l}\text { Training environment in the bank helped me to increase job perfor- } \\
\text { mance. }\end{array}$ & 3.82 & 0.91 \\
\hline $\begin{array}{l}\text { Training environment in the bank helped me to cooperate with other to } \\
\text { increase job performance. }\end{array}$ & 3.91 & 0.97 \\
\hline $\begin{array}{l}\text { Training environment in the bank helped participating each employee so } \\
\text { that overall job performance has increased. }\end{array}$ & 3.62 & 1.1 \\
\hline $\begin{array}{l}\text { Training provided by the office helped me to change knowledge into } \\
\text { skills which helps to improve performance. }\end{array}$ & 3.73 & 0.83 \\
\hline $\begin{array}{l}\text { Training provided by the office helped me increasing confidence level to } \\
\text { improve performance. }\end{array}$ & 3.74 & 0.74 \\
\hline $\begin{array}{l}\text { Training programs help me to decrease wastage of time and other re- } \\
\text { sources which increases the performance. }\end{array}$ & 3.74 & 0.89 \\
\hline $\begin{array}{l}\text { Training method used to transfer the knowledge helped me to increase } \\
\text { job performance. }\end{array}$ & 3.67 & 0.91 \\
\hline $\begin{array}{l}\text { Training linkage with reward system motivated me to increase the effort } \\
\text { to the job. }\end{array}$ & 3.85 & 0.92 \\
\hline $\begin{array}{l}\text { Training-reward linkage helped to empowerment employees which } \\
\text { increases the job performance. }\end{array}$ & 3.93 & 1.05 \\
\hline Training-reward linkage helped me to increase the quality of work. & 3.65 & 0.53 \\
\hline $\begin{array}{l}\text { Training-reward linkage ensures the promotion which helped me to be } \\
\text { one of the best performers. }\end{array}$ & 3.87 & 0.81 \\
\hline Weighted Average Mean satisfaction & $\mathbf{3 . 7 7}$ & $\mathbf{0 . 8 8}$ \\
\hline
\end{tabular}


The overall i.e. weighted average mean satisfaction regarding performance improvement through training culture of the bank is obtained to be 3.77 with s. d. 0.88 indicating that respondent agree with the statements stating the improving performance through training culture in the banking industry. There is not greater variation in the response of respondents (s. d. 0.88). This provides sufficient evidence proving that the training culture helps to improve employee job performance.

Correlation analysis has been carried out to examine the direction and magnitude of relationship of training culture and employee performance. Table 4 shows the correlation between employee job performance and dimensions of training culture.

\section{Table 4}

\section{Pearson's correlation matrix describing correlation between employee performance and factors of training culture}

This table presents bivariate Pearson correlation coefficient between employee performance and training culture dimensions in Nepali commercial and development banks. Factors notations are used as: employee performance EP, Training Environment TE, Training methods TM and Training-reward Linkage TRL.

\begin{tabular}{lllll}
\hline & TE & TM & TRL & EP \\
\hline TE & 1 & & & \\
TM & $0.523^{* *}$ & 1 & & \\
TRL & $0.394^{* *}$ & $0.416^{* *}$ & 1 & \\
EP & $0.583^{* *}$ & $0.619^{* *}$ & $0.574^{* *}$ & 1 \\
\hline
\end{tabular}

Notes:

1. ${ }^{* *}$ sign indicates that correlation is significant at 1 percent level.

2. ${ }^{*}$ sign indicates that correlation is significant at 5 percent level.

The result reveals that there is positive relationship between employee job performance and all the factors of training culture. EP has highest positive relationship $\left(r=0.619^{* *}\right)$ with training methods while positive but smallest among other is with training-rewards linkage. This indicates that training methods have direct concern to translate knowledge into skills and immediate effect on job performance. Training-reward linkage is the area of organizational policy and trust of employees towards. This has raised the emergence of ensuring the growth opportunities be linked with training participation and training transfer.

Training culture satisfaction as well as the employee job performance may vary with the types of bank i.e. commercial banks and development banks. They also may be different in gender of the employee respondents. Table 5 presents the t-statistics to test whether size 
of bank mediates the employee satisfaction and employee performance through training culture. Descriptive statistics shows the difference in mean satisfaction value. To test whether such differences are by chance or they are statistically varied, Levene's Test for Equality of Variance is used.

Table 5

Mediating effect of types of bank on employee satisfaction and employee job performance

\begin{tabular}{|c|l|c|c|r|c|}
\hline \multicolumn{2}{|c|}{} & \multicolumn{2}{c|}{$\begin{array}{c}\text { Levene's Test for } \\
\text { Equality of Variances }\end{array}$} & \multicolumn{2}{c|}{ t-test for Equality of Means } \\
\cline { 3 - 6 } \multicolumn{2}{|c|}{} & Sig. & t & Sig. (2-tailed) & \\
\hline \multirow{2}{*}{ TS } & Equal variances assumed & 10.888 & 0.001 & -5.777 & 0.000 \\
\cline { 2 - 6 } & Equal Variances not assumed & & & -7.407 & 0.000 \\
\hline \multirow{2}{*}{ EP } & Equal variances assumed & 2.438 & 0.022 & -6.863 & 0.000 \\
\cline { 2 - 6 } & Equal Variances not assumed & & & -8.392 & 0.000 \\
\hline
\end{tabular}

Result reveals that there is significant evidence for accepting the hypothesis that the satisfaction level of employee respondents from commercial banks and development banks differ significantly. Likewise, the hypothesis that there is significant difference between the employee job performance of the trained employees in commercial and development banks is accepted.

Likewise, gender can have mediating role in satisfaction from training culture and employee job performance. Table 6 shows statistics for testing the mediating effect of gender on satisfaction from training culture and employee performance.

\section{Table 6}

Mediating effect of gender on employee satisfaction and employee job performance

\begin{tabular}{|c|l|r|r|r|r|}
\hline \multicolumn{2}{|c|}{ F } & \multicolumn{2}{c|}{$\begin{array}{c}\text { Levene's Test } \\
\text { for Equality of } \\
\text { Variances }\end{array}$} & \multicolumn{2}{c|}{ t-test for Equality of Means } \\
\cline { 3 - 6 } \multicolumn{2}{|c|}{} & Sig. & \multicolumn{1}{c|}{ t } & Sig. (2-tailed) & \\
\hline \multirow{2}{*}{ TS } & Equal variances assumed & 9.792 & 0.005 & -2.335 & 0.000 \\
\cline { 2 - 6 } & $\begin{array}{l}\text { Equal Variances not } \\
\text { assumed }\end{array}$ & & & -5.701 & 0.000 \\
\hline \multirow{2}{*}{ EP } & Equal variances assumed & 3.438 & 0.036 & -8.363 & 0.000 \\
\cline { 2 - 6 } & $\begin{array}{l}\text { Equal Variances not } \\
\text { assumed }\end{array}$ & & & -10.312 & 0.000 \\
\hline
\end{tabular}

Table 6 reveals that the satisfaction level of male and female from training culture differ significantly. In the similar fashion, the gender mediates the employee job performance. 
Conclusion

The major conclusion of this study is that Nepali banking industry has established the training culture as to compete in most competitive business environment. Training not only increases the job skills but also motivates the employee which leads increase in the employee job performance. Through training culture, organizations can fulfill the mandatory provision to develop employee's wellbeing and guarantee of growth opportunities. Training culture is one of the most essential dimensions in an organization's development and success. It is hence vital for an employer to understand what motivates the employees and how to maximize their overall job performance. Result shows the positive and significant correlation between employee performance and components of training culture. Study also concludes that training method is the major factor of training culture followed by training environment and training-reward linkage. It has been found that types of the bank and gender of employee respondent mediate the employee satisfaction and employee job performance. This indicates that the training effectiveness in commercial and development banks is not uniform. Likewise, male and female are also not equally satisfied from the training culture.

\section{References}

Almazari, A. A., A. A.-Z. (2014). The impact of effective human resources management practices on the financial performance of the Saudi banks. Review of Integrative Business and Economics, vol 3(1), 327-336.

Alrawabdeh, W. (2014). How employees' loyalty programs impact organizational performance within Jordanian banks?. International Journal of Business Research, 7(9), 119-228.

Battistelli, A. (2009). The influence of the organizational context on training motivation. Journal of E-Learning and Knowledge Society, 4(1), 200-209.

Bulut, C., \& Culha, O. (2010). The effects of organizational training on organizational commitment. International Journal of Training and Development, 14(4), 309-322.

Chaudhary, N., \& Sharma, B. (2012). Impact of employee motivation on performance (productivity) in private organization. International Journal of Business Trends and Technology, 2(4), 29-35.

Chiaburu, S., D., Teklab, \& G., A. (2005). Individual and contextual influences on multiple dimensions of training effectiveness. Journal of European Industrial Training, Vol 20, p. 282-290. 
Dabale, W. P., Jagero, N., \& Nyauchi, M. (2014). The relationship between training and employee performance: the case of Zimbabwe. International Journal of Human Resource Studies, 4(4), 61

Falola, H. O., Osibanjo, A. O., \& Ojo, S. I. (2014). Effectiveness of training and development on employees' performance and organization competitiveness in the Nigerian banking industry. Bulletin of the Transylvania University of Brasov Economic Sciences, 7(1), 161-170.

Garman,A.N.,Davis-Lenane, \&Corrigan,P.(2003).FactorStructureofthe Transformational Leadership model in Human service Teams. Journal of Organisational Behaviour, Vol 24(6), 803-812.

Hameed, A., \& Waheed, A. (2011). Employee development and its affect on employee performance a conceptual framework. International Journal of Business and Social Science, 2(13), 224-232.

Hanif, F. (2013). Impact of training on employee's development and performance in hotel industry of Lahore, Pakistan. Journal of Business Studies Quarterly, 4(4), 68-82.

Hofstede, G. (1998). Attitudes, values and organizational culture: Disentangling the concepts. Organization studies, 19(3), 477-493.

Hossain, M. K., \& Hossain, A. (2012). Factors affecting employee's motivation in the fast food industry. Research Journal of Economics, business and ICT, 5(1), 21-30.

Idrees, Z., Xinping, X., Shafi, K., Hua, L., \& Nazeer, A. (2015). Consumer's brand trust and its link to brand loyalty. American Journal of Business, Economics and Management, $3(2), 34$.

Khan, M. I. (2012). The impact of training and motivation on performance of employees. Journal of Business Review, 7(2), 84-95.

Kum, F. D., Cowden, R., \& Karodia, A. M. (2014). The impact of training and development on employee performance. Singaporean Journal of Business Economics, and Management Study, 3(3), 72-105.

Peteraf, M.A. and Niazi (1993). The Cornerstones of Competitive Advantage: A ResourceBased View. Strategic Management Journal, Vol 14(3), 179-192. 
Polo, F., Cervai, S., \& Kantola, J. (2018). Training culture: a new conceptualization to capture values and meanings of training in organizations. Journal of Workplace Learning. https://doi.org/10.1108/JWL-01-2018-0024.

Saeed, M. M. \& Asghar, M. (2012). Examining the relationship between training, motivation and employees job performance-the moderating role of person job fit. Journal of Basic and Applied Scientific Research, 2(12), 12177-12183.

Shahzadi, I. (2014). Impact of employee motivation on employee performance. European Journal of Business and Management, 6(23), 159-166.

Singh, G. (2014). Impact of training on job performance at diesel locomotive work. Journal of Management Research and Analysis, 1(1), 27-41.

Smith, P. M. (2000). HRM practices and organisational commitment. Canadian Journal of Administrative Sciences, Vol. 17 No. 4, 319-31.

Tahir, N., Yousafzai, I. K., Jan, S., \& Hashim, M. (2014). The impact of training and development on employee's performance and productivity. International Journal of Academic Research in Business and Social Sciences, 4(4), 86.

Wahab, S. R. A., Hussain, A., Zadeh, A. A., Shah, F. A., \& Hussain, J. (2014). Employees' perception and motivation towards training and development programs in health sector of Pakistan. Middle-East Journal of Scientific Research, 19(10), 1361-1367.

\section{Appendix}

Survey Questionnaire on Training Culture and Employees Performance in Nepalese Banking Industry

Dear Respondent,

I am pleased to inform you that I am undertaking a research work on Training Culture and Employees Performance in Nepalese Banking Industry. For your kind information, it is purely an academic work and your response will be kept confidential and anonymous. Information provided by you will be analyzed at aggregate level.

Thank you for your time, co-operation and contribution to the study. I shall be pleased to send you a copy of the findings of the study if you wish so.

Thanking you

Prakash Kumar Gautam 
Assistant Professor, Tribhuvan University

gdpconsultingnepal@gmail.com

General information of the Respondent

Name of the bank:

Commercial/Development

\section{Gender}

\begin{tabular}{|l|l|l|}
\hline Female & Male & Other \\
\hline & & \\
\hline
\end{tabular}

Age

\begin{tabular}{|l|l|l|l|l|}
\hline Below 25 yrs. & $26-35$ yrs. & $36-45$ yrs. & $46-55$ yrs. & above 55 yrs. \\
\hline & & & & \\
\hline
\end{tabular}

\section{Current work position}

\begin{tabular}{|l|l|l|l|}
\hline Senior manager & Manager & Officer & Assistant \\
\hline & & & \\
\hline
\end{tabular}

\section{Academic qualification}

\begin{tabular}{|l|l|l|l|}
\hline Intermediate & Bachelor Degree & Master degree & MPhil. /PhD \\
\hline & & & \\
\hline
\end{tabular}

\section{Work experience in banking sector}

\begin{tabular}{|l|l|l|l|l|}
\hline Below 2 yrs. & $2-5$ yrs. & $6-10$ yrs. & $10-15$ yrs. & above 15 yrs. \\
\hline & & & & \\
\hline
\end{tabular}

\section{Work experience in this bank}

\begin{tabular}{|l|l|l|l|l|}
\hline Below 2 yrs. & $2-5$ yrs. & $6-10$ yrs. & $10-15$ yrs. & above 15 yrs. \\
\hline & & & & \\
\hline
\end{tabular}

\section{Overview regarding training culture of the organization}

Please mark a tick in an appropriate response that best describe your view and perception towards training culture in your organization. It is a humble request to realize each statement. 


\section{Training culture component}

Is there training need assessment in regular basis in your organization?

Does your organization follow on-the-job and off-the-job training as on issue of training?

Is the training duration for each training session in an average is sufficient?

Is there regular training and development budget in your organization?

Does your organization provide sufficient training material in training?

Do employees get training opportunity unbiased in your organization?

Does your organization provide credit or priority to the trained employees?

\section{Training Culture Components}

Please mark a tick in an appropriate response that best describe your view and perception towards training culture. It is a humble request to realize each statement as me is used for you i.e. respondent. [1- Strongly Disagree, 2- Disagree, 3- Neutral, 4- Agree, 5- Strongly Agree]

\begin{tabular}{|c|c|c|c|c|c|c|}
\hline S.N & Training Environment & 1 & 2 & 3 & 4 & 5 \\
\hline A & $\begin{array}{l}\text { My organization gives feedback on performance before and } \\
\text { after training. }\end{array}$ & & & & & \\
\hline B & $\begin{array}{l}\text { My organization uses appropriate training layout according to } \\
\text { training purpose }\end{array}$ & & & & & \\
\hline $\mathrm{C}$ & $\begin{array}{l}\text { My organization has the provision of evaluation of training } \\
\text { program at the end of the training program. }\end{array}$ & & & & & \\
\hline $\mathrm{D}$ & $\begin{array}{l}\text { My organization provides different training environment for } \\
\text { different trainings. }\end{array}$ & & & & & \\
\hline $\mathrm{E}$ & $\begin{array}{l}\text { Trainers manage the encouraging environments during training in } \\
\text { the organization. }\end{array}$ & & & & & \\
\hline $\mathrm{F}$ & Trainees can discuss openly at training session on the main issues & & & & & \\
\hline
\end{tabular}




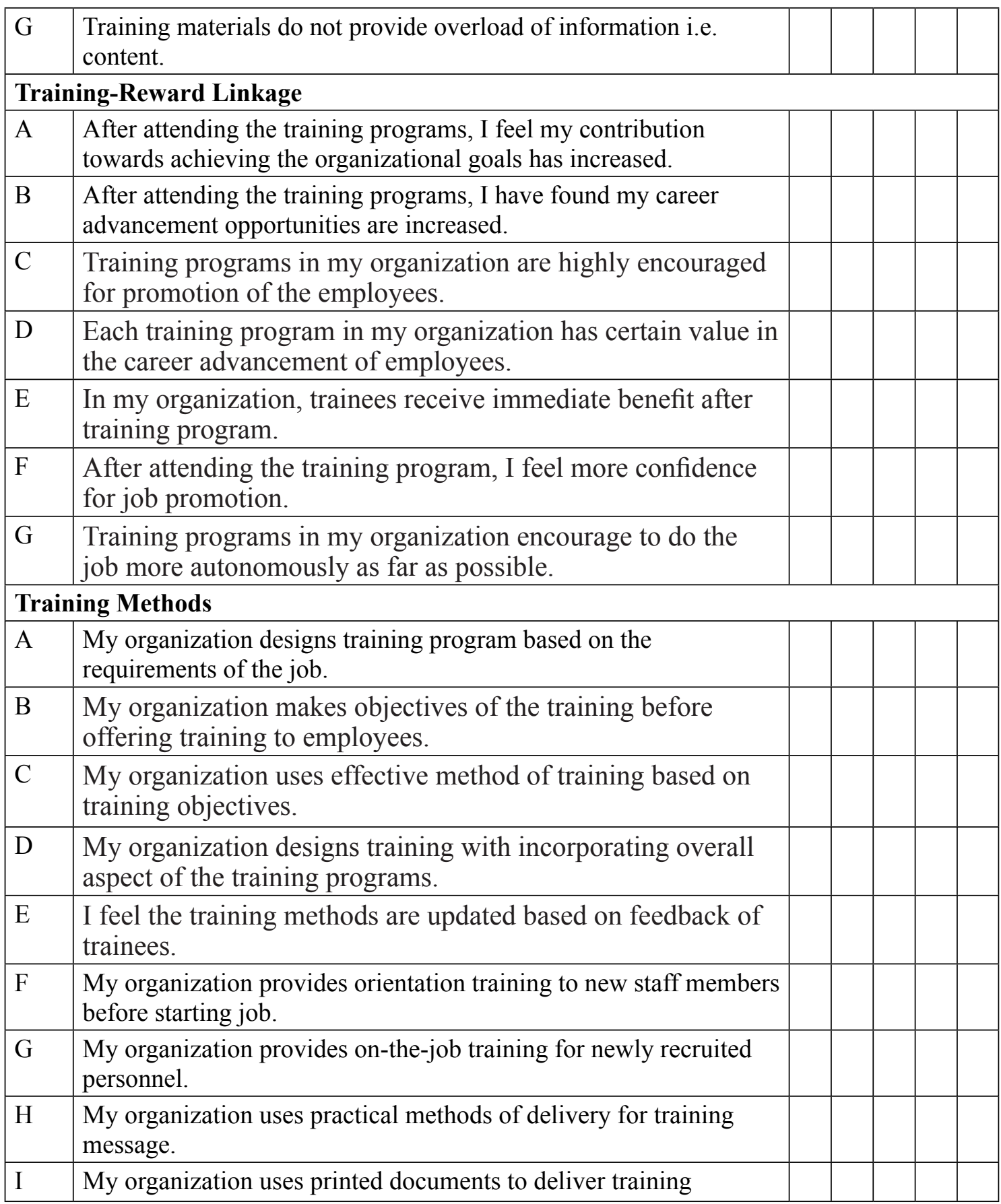

\section{Employee performance as result of Training Culture}

Please mark a tick in an appropriate response that best describe your perception towards the role of training culture in employee performance. It is a humble request to realize 
each statement as me is used for you i.e. respondent. [1- Strongly Disagree, 2- Disagree, 3- Neutral, 4- Agree, 5- Strongly Agree]

\begin{tabular}{|c|c|c|c|c|c|}
\hline Statements & 1 & 2 & 3 & 4 & 5 \\
\hline $\begin{array}{l}\text { Training environment in the bank helped me to increase job } \\
\text { performance. }\end{array}$ & & & & & \\
\hline $\begin{array}{l}\text { Training environment in the bank helped me to cooperate with } \\
\text { other to increase job performance. }\end{array}$ & & & & & \\
\hline $\begin{array}{l}\text { Training environment in the bank helped participating each } \\
\text { employee so that overall job performance has increased. }\end{array}$ & & & & & \\
\hline $\begin{array}{l}\text { Training provided by the office helped me to change knowledge } \\
\text { into skills which helps to improve performance. }\end{array}$ & & & & & \\
\hline $\begin{array}{l}\text { Training provided by the office helped me increasing confidence } \\
\text { level to improve performance. }\end{array}$ & & & & & \\
\hline $\begin{array}{l}\text { Training programs help me to decrease wastage of time and other } \\
\text { resources which increases the performance. }\end{array}$ & & & & & \\
\hline $\begin{array}{l}\text { Training method used to transfer the knowledge helped me to } \\
\text { increase job performance. }\end{array}$ & & & & & \\
\hline $\begin{array}{l}\text { Training linkage with reward system motivated me to increase the } \\
\text { effort to the job. }\end{array}$ & & & & & \\
\hline $\begin{array}{l}\text { Training-reward linkage helped to empowerment employees which } \\
\text { increases the job performance. }\end{array}$ & & & & & \\
\hline Training-reward linkage helped me to increase the quality of work. & & & & & \\
\hline $\begin{array}{l}\text { Training-reward linkage ensures the promotion which helped me to } \\
\text { be one of the best performers. }\end{array}$ & & & & & \\
\hline
\end{tabular}

If you have any comments or suggestions regarding training programs, please mention here:

Thank you for your kind cooperation. 